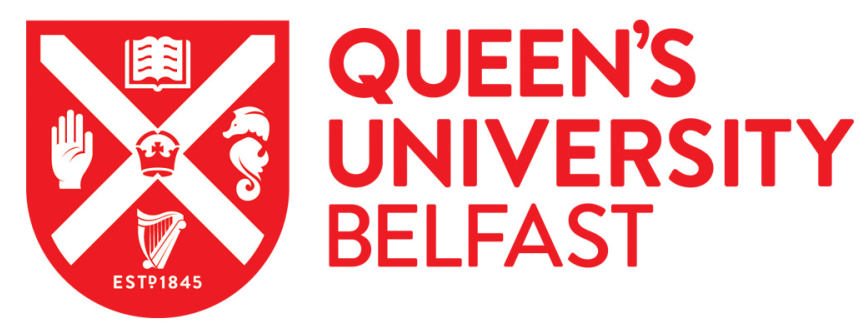

\title{
Using multi-criteria and thermodynamic analysis to optimize process parameters for mixed reforming of biogas
}

De Rosa, F., Smyth, B. M., McCullough, G., \& Goguet, A. (2018). Using multi-criteria and thermodynamic analysis to optimize process parameters for mixed reforming of biogas. International Journal of Hydrogen Energy. https://doi.org/10.1016/j.ijhydene.2018.08.127

Published in:

International Journal of Hydrogen Energy

Document Version:

Peer reviewed version

Queen's University Belfast - Research Portal:

Link to publication record in Queen's University Belfast Research Portal

Publisher rights

( 2018 Hydrogen Energy Publications LLC. Published by Elsevier Ltd. This manuscript is distributed under a Creative Commons AttributionNonCommercial-NoDerivs License (https://creativecommons.org/licenses/by-nc-nd/4.0/), which permits distribution and reproduction for noncommercial purposes, provided the author and source are cited.

\section{General rights}

Copyright for the publications made accessible via the Queen's University Belfast Research Portal is retained by the author(s) and / or other copyright owners and it is a condition of accessing these publications that users recognise and abide by the legal requirements associated with these rights.

Take down policy

The Research Portal is Queen's institutional repository that provides access to Queen's research output. Every effort has been made to ensure that content in the Research Portal does not infringe any person's rights, or applicable UK laws. If you discover content in the Research Portal that you believe breaches copyright or violates any law, please contact openaccess@qub.ac.uk. 


\title{
Using multi-criteria and thermodynamic analysis to optimize process parameters for mixed reforming of biogas
}

\author{
F. De Rosa ${ }^{1}$, B.M. Smyth²*, G. McCullough ${ }^{2}$, A. Goguet ${ }^{1}$ \\ ${ }^{1}$ School of Chemistry and Chemical Engineering, Queen's University Belfast, BT9 5AG, UK \\ ${ }^{2}$ School of Mechanical and Aerospace Engineering, Queen's University Belfast, BT9 5AH, \\ $U K$ \\ *corresponding author: beatrice.smyth@qub.ac.uk
}

\begin{abstract}
Syngas is a gas mixture that can be obtained from a variety of raw materials and used as source of hydrogen. Biogas is an interesting raw material from which to produce syngas via thermocatalytic reforming because it is abundant, can be obtained from low-cost feedstock, and is potentially carbon-neutral. However, difficulties arise because biogas composition changes from source to source, the reforming process can be quite energy-intensive and there is associated catalyst deactivation through carbon deposition. Mixed reforming of biogas with steam and/or air shows benefits in terms of carbon deposition and energy requirements, but the reaction network is complicated and finding the optimal operating conditions is not trivial. Although several analytical techniques have been used in the literature to find the optimal process conditions, a direct comparison is difficult due to the different criteria and/or boundaries considered. This paper aims to develop a novel and comprehensive methodology for identifying the optimal thermodynamic operating conditions (temperature and feed ratios) for mixed reforming of biogas with air and steam, based on equilibrium data manipulated via two multi-criteria decision making (MCDM) techniques in series, namely the entropy and the TOPSIS methods. The optimal scenario is when biogas made of $50-60 \% \mathrm{CH}_{4}$ in $\mathrm{CO}_{2}$ is reacted in the reforming reactor at $\mathrm{CH}_{4} / \mathrm{CO}_{2} / \mathrm{O}_{2} / \mathrm{H}_{2} \mathrm{O}=1 / 1-0.67 / 0-0.1 / 3-2.4$ and $790-735{ }^{\circ} \mathrm{C}$, resulting in a product stream composed of $66-65 \% \mathrm{H}_{2}, 0.8-1 \% \mathrm{CO}$ and $33-28 \% \mathrm{CO}_{2}$ on a dry basis after the water-gas shift section. At these conditions the hydrogen yield and the conversion of methane in the biogas can be simultaneously maximized, while the yield of solid carbon and the net energy requirement of the overall process can be minimized. In conjunction with the numerical results, the main outcome of this paper is the development of a novel method based on MCDM techniques for the optimization of the operating conditions in a network of reactions.
\end{abstract}

Keywords Biogas, reforming, optimization, multi-criteria, entropy, TOPSIS 


\section{Introduction}

\subsection{Hydrogen production via biogas}

Hydrogen is considered by many as the fuel of the future, with its best use in terms of energy efficiency being in fuel cells $[1,2]$. Any improvement in the fuel cell field depends on developments in hydrogen production, storage and delivery technologies [3]. Nowadays hydrogen is obtained mainly through steam reforming (SRM) (Equation 1) or partial oxidation (POx) of methane/natural gas (Equation 2), followed by the water-gas shift (WGS) reaction (Equation 3) [4-6]. Biomass-derived gas through anaerobic digestion (AD), or simply biogas, represents a sustainable alternative to natural gas [7-11], since its utilization can result in a neutral carbon balance, depending on the feedstock [12], and it can displace fossil fuels [13], which are the main contributors to greenhouse gas (GHG) emissions [14, 15].

Biogas has a typical composition of $50-70 \% \mathrm{CH}_{4}, 30-50 \% \mathrm{CO}_{2}$ and minor amount of $\mathrm{H}_{2} \mathrm{O}, \mathrm{H}_{2} \mathrm{~S}, \mathrm{NH}_{3}, \mathrm{H}_{2}, \mathrm{~N}_{2}$ and $\mathrm{O}_{2}$ depending on the source [16]. Once contaminants have been removed, biogas can be used as raw material in the dry reforming of methane (DRM) with $\mathrm{CO}_{2}$ (Equation 4) to produce hydrogen; compared to SRM, the reaction is slightly more endothermic ( 247 vs. $\left.209 \mathrm{~kJ} \mathrm{~mol}^{-1}\right)$ and the product stream has a lower $\mathrm{H}_{2} / \mathrm{CO}$ ratio $\left(\mathrm{H}_{2} / \mathrm{CO}=1\right.$ vs. 3 ). The main problem associated with the SRM and DRM reactions is solid carbon (also known as coke) formation via methane cracking (Equation 5) and CO disproportionation (Equation 6).

The combination of endothermic reactions $(\Delta H>0)$ with $\mathrm{PO}_{\mathrm{X}}(\Delta H<0)$ is called autothermal reforming (ATR), because a fraction of the heat required by the process is generated by combustion of part of the feed with oxygen $[17,18]$. The combination of SRM, DRM and $\mathrm{PO}$ is known as mixed reforming or tri-reforming (TRI-R). It has gained attention lately [19-23] because of the advantage of lowered carbon deposition and energy requirement, however, this is at the expense of the loss of some valuable $\mathrm{CO}$ (Equation 7) and $\mathrm{H}_{2}$ (Equation 8) via oxidation.

\begin{tabular}{|c|c|c|c|}
\hline Steam reforming of methane & $\mathrm{CH}_{4}+\mathrm{H}_{2} \mathrm{O} \rightleftarrows \mathrm{CO}+3 \mathrm{H}_{2}$ & $\Delta H_{298}^{0}=208.813 \mathrm{~kJ} \mathrm{~mol}^{-1}$ & Equation 1 \\
\hline Partial oxidation of methane & $\mathrm{CH}_{4}+0.5 \mathrm{O}_{2} \rightarrow \mathrm{CO}+2 \mathrm{H}_{2}$ & $\Delta H_{298}^{0}=-36 \mathrm{~kJ} \mathrm{~mol}^{-1}$ & Equation 2 \\
\hline Water-gas shift & $\mathrm{CO}+\mathrm{H}_{2} \mathrm{O} \rightleftarrows \mathrm{CO}_{2}+\mathrm{H}_{2}$ & $\Delta H_{298}^{0}=-41.166 \mathrm{~kJ} \mathrm{~mol}^{-1}$ & Equation 3 \\
\hline Dry reforming of methane & $\mathrm{CH}_{4}+\mathrm{CO}_{2} \rightleftarrows 2 \mathrm{CO}+2 \mathrm{H}_{2}$ & $\Delta H_{298}^{0}=246.979 \mathrm{~kJ} \mathrm{~mol}^{-1}$ & Equation 4 \\
\hline Methane cracking & $\mathrm{CH}_{4} \rightleftarrows \mathrm{C}+2 \mathrm{H}_{2}$ & $\Delta H_{298}^{0}=74.52 \mathrm{~kJ} \mathrm{~mol}^{-1}$ & Equation 5 \\
\hline CO disproportionation & $2 \mathrm{CO} \rightleftarrows \mathrm{CO}_{2}+\mathrm{C}$ & $\Delta H^{0}{ }_{298}=-172.459 \mathrm{~kJ} \mathrm{~mol}^{-1}$ & Equation 6 \\
\hline Oxidation of $\mathrm{CO}$ & $\mathrm{CO}+0.5 \mathrm{O}_{2} \rightarrow \mathrm{CO}_{2}$ & $\Delta H_{298}^{0}=-282.984 \mathrm{~kJ} \mathrm{~mol}^{-1}$ & Equation 7 \\
\hline Oxidation of $\mathrm{H}_{2}$ & $\mathrm{H}_{2}+0.5 \mathrm{O}_{2} \rightarrow \mathrm{H}_{2} \mathrm{O}$ & $\Delta H_{298}^{0}=-241.818 \mathrm{~kJ} \mathrm{~mol}^{-1}$ & Equation 8 \\
\hline
\end{tabular}




\subsection{Review of the literature}

Considering that two thirds of the overall cost of hydrogen production are for feed, fuel and utilities [24], benefits in the process can be obtained by lowering the operating costs (e.g. through better control of carbon limits to extend catalyst lifetimes), by selecting catalysts which allow flexibility by using low-cost feedstock (e.g. biogas), and by selecting optimum process conditions giving low energy consumption. Given the various combinations of possible reactions for the production of hydrogen from methane/biogas (Equation 1 - Equation 8), the optimization of the operating conditions represents a trade-off between multiple criteria, whose relationships are not always clear. A direct comparison of the results of previous research on the optimization of mixed reforming of methane/biogas is difficult because of the different techniques, criteria, boundaries, and combinations of reactions considered (Table 1).

Seo et al. [25] studied the equilibrium values during SRM, POx and autothermal reforming, together with the energy required by the system, in order to maximize the conversion of methane and minimize the yield of solid carbon (biogas was not considered in the feed). The maximum allowable temperature was assumed to be $800{ }^{\circ} \mathrm{C}$, and the results showed that, in terms of energy cost, the POx reforming system is more efficient than other systems for the production of the same amount of hydrogen from $\mathrm{CH}_{4}$. The results, however, are not readily comparable with other studies because of the different configurations used during the simulation of the processes. The consumption of thermal energy is a key issue in the design of a reforming system, as demonstrated by Avila-Neto et al [26], whose thermodynamic analysis was focused on the maximization of hydrogen yield by using the equilibrium constant and Lagrange's multipliers method. The authors studied steam, dry, oxidative and autothermal reforming of methane. The analysis comprised a complicated system of non-linear algebraic equations to be solved numerically. Jarungthammachote [27] studied the combination of SRM, DRM and POx, by analysing the equilibrium data via a parametric study in order to find the operating conditions which maximize solely the hydrogen yield. A fixed composition of biogas was assumed in this analysis, which excluded a WGS stage. An energy assessment of the different processes was not included. Vita et al. [28] and Effendi et al. [29] performed experimental optimization of biogas reforming using a $\mathrm{Ni} / \mathrm{CeO}_{2}$ and $\mathrm{Ni} / \mathrm{Al}_{2} \mathrm{O}_{3}$ catalyst, a fixed $\mathrm{CO}_{2} / \mathrm{CH}_{4}$ ratio, and quite narrow experimental conditions. The study focused on the reforming step alone, and did not include energy considerations. Larentis et al [30] investigated process optimization for the combined dry reforming and partial oxidation process of natural gas (79 $\left.\% \mathrm{CH}_{4}, 17 \% \mathrm{C}_{2} \mathrm{H}_{6}, 4 \% \mathrm{C}_{3} \mathrm{H}_{8}\right)$, through a combination of experimental results obtained with a 
$\mathrm{Pt} / \mathrm{Al}_{2} \mathrm{O}_{3}$ catalyst, mathematical and phenomenological modeling. The study did not consider steam in the feed, and the concentration of $\mathrm{CO}_{2}$ in methane was fixed at $27 \%$.

While previous studies have investigated aspects of the optimisation of hydrogen production, there is a lack of existing research using a comprehensive approach to take the relevant criteria (i.e. energy requirements, carbon formation and the equilibrium composition of hydrogen-rich gas), their mutual relationships, all reaction stages, and the range of possible combinations of network reactions into account. MCDM techniques are used in engineering, business and many other fields [31-33] to assist in ranking available alternatives when complex multiple criteria have to be considered simultaneously [34], and present a possible solution to the problem. However, to the authors' knowledge, MCDM techniques have never been used before for the optimization of the process conditions in a chemical reaction network. Recent recommendations for best practice are to use MCDM techniques like the entropy method in series with Technique for Order Preference by Similarity to the Ideal Solution (TOPSIS) [35]. The combination of the two techniques has been used for safety evaluation of coal mines [36], information system selection [37], ecological-economic efficiency evaluation of green technologies [38], and building energy performance benchmarking [39], amongst others. The advantages of these techniques are that TOPSIS evaluates alternatives simultaneously considering all the criteria of interest with straightforward computation [39] [40], while the entropy method overcomes subjectivity when assigning the weights to the evaluation criteria [41] [42].

The aim of this paper is to fill the knowledge gap by developing a clear and comprehensive methodology which considers various compositions of biogas, combinations of reactions, and process conditions in order to make recommendations for optimizing the operating conditions of mixed reforming of methane/biogas. Along with the numerical results, the main novelty is the development of a methodology for the analysis of a chemical reaction network. 
Table 1 - Optimization of methane/biogas reforming from literature

\begin{tabular}{|c|c|c|c|c|c|c|c|}
\hline$\overline{\mathrm{CH}_{4} / \mathrm{CO}_{2} / \mathrm{O}_{2} / \mathrm{H}_{2} \mathrm{O}_{-} \text {range }}$ & $\mathbf{T}\left({ }^{\circ} \mathrm{C}\right) \_$range & $\mathbf{P}(\mathbf{a t m})$ & $\mathrm{CH}_{4} / \mathrm{CO}_{2} / \mathrm{O}_{2} / \mathrm{H}_{2} \mathrm{O}_{-}$optimal & T( $\left(^{\circ} \mathbf{C}\right) \_$optimal & Target & Methodology & Ref. \\
\hline $1 / 0 / 0 / 0.6-3$ & $<800$ & 1 & $1 / 0 / 0 / 1.9$ & 800 & Maximize $\mathrm{x}_{\mathrm{CH} 4} ;$ minimize $\mathrm{Y}_{\mathrm{C}}$ & Thermodynamic analysis & {$[25]$} \\
\hline $1 / 0 / 0-1.2$ & & 1 & $1 / 0 / 0.6$ & 800 & & & {$[25]$} \\
\hline $1 / 0 / 0-1 / 0-1.2$ & & 1 & $1 / 0 / 0.58 / 0.35$ & 800 & & & {$[25]$} \\
\hline $1 / 0 / 0 / 0-4$ & $100-1000$ & 1 & $1 / 0 / 0 / 4$ & 846.85 & Maximize $\mathrm{Y}_{\mathrm{H} 2}$ & $\begin{array}{l}\text { Thermodynamic analysis via Langrange's multipliers and } \\
\text { equilibrium constant method }\end{array}$ & {$[26]$} \\
\hline $1 / 0-3$ & $100-1000$ & 1 & $1 / 1$ & 700 & & & {$[26]$} \\
\hline $\begin{array}{l}1 / 0.54 / 0.46-0.92 / 0.77- \\
12.3\end{array}$ & & 1 & $1 / 0.54 / 0.66-0.7 / 6.15-7.69$ & 800 & Maximize $\mathrm{Y}_{\mathrm{H} 2}$ & Thermochemical equilibrium study & [27] \\
\hline $1 / 0.67 / 0.05-0.1 / 0.3-0.7$ & $800-900$ & 1 & $1 / 0.67 / 0.1 / 0.3$ & 800 & Maximize activity and stability & Experimental $\left(\mathrm{Ni} / \mathrm{CeO}_{2}\right)$ & {$[28]$} \\
\hline $1 / 0.67 / 0 / 0-5$ & $627-927$ & 1 & $1 / 0.67 / 0 / 2.5$ & 750 & Low CO concentration & Experimental $\left(\mathrm{Ni} / \mathrm{Al}_{2} \mathrm{O}_{3}\right)$ & {$[29]$} \\
\hline $1 / 0.37 / 0.25-0.55$ & $600-1100$ & 1 & $1 / 0.37 / 0.55$ & 950 & $\begin{array}{l}\text { Maximize } \mathrm{x}_{\mathrm{CH} 4}, \mathrm{~S}_{\mathrm{CO}} ; \text { minimize } \\
\mathrm{H}_{2} / \mathrm{CO}, \mathrm{Y}_{\mathrm{H} 2 \mathrm{O}}\end{array}$ & $\begin{array}{l}\text { Experimental }\left(\mathrm{Pt} / \mathrm{Al}_{2} \mathrm{O}_{3}\right)+\text { empirical and phenomenological } \\
\text { modelling }\end{array}$ & [30] \\
\hline $1 / 0.33-1$ & $400-1400$ & 1 & $1 / 1$ & 1100 & $\begin{array}{l}\text { Maximize } \mathrm{Y}_{\mathrm{H} 2} ; \quad \text { minimize } \\
\text { energy usage }\end{array}$ & Minimization of Gibbs free energy & [43] \\
\hline $1 / 1 / 0 / 2-6$ & $400-1400$ & 1 & $1 / 1 / 0 / 2$ & 850 & & & [43] \\
\hline $1 / 0 / 0 / 1-3$ & $400-1400$ & 1 & $1 / 0 / 0 / 1$ & 900 & & & [43] \\
\hline $1 / 1 / 0-0.5$ & $327-1027$ & 1 & $1 / 0.8-1 / 0.1-0.2$ & 926.85 & Maximize $\mathrm{Y}_{\mathrm{H} 2}$ & Lagrange's undetermined multiplier method & [44] \\
\hline $1 / 0 / 1-5$ & $500-1000$ & 1 & $1 / 0 / 2-3$ & $700-800$ & $\begin{array}{l}\text { Maximize } \quad x_{\mathrm{CH} 4}, \quad \mathrm{x}_{\mathrm{H} 2 \mathrm{O}}, \quad \mathrm{Y}_{\mathrm{H} 2} ; \\
\text { minimize } \mathrm{Y}_{\mathrm{C}}\end{array}$ & Minimization of Gibbs free energy & [45] \\
\hline $1 / 0.5-3 / 0.1-0.5 / 0.5-3$ & $500-1000$ & 1 & $1 / 0.8-1 / 0.1-0.2$ & $>800$ & & & {$[45]$} \\
\hline $1 / 0.7 / 0.06$ & $500-1000$ & 1 & $1 / 0.7 / 0.06$ & 850 & $\mathrm{H}_{2} / \mathrm{CO}=1.6-1.7$ & Parameter sensitivity analyses & {$[46]$} \\
\hline $1 / 0.25-4$ & $300-1100$ & 1 & $1 / 1-2$ & $800-1100$ & Maximize $\mathrm{Y}_{\mathrm{H} 2} ;$ minimize $\mathrm{Y}_{\mathrm{C}}$ & Numerical simulation model & [47] \\
\hline
\end{tabular}




\section{Methodology}

\subsection{Overview}

In order to develop the MCDM methodology with four variables (temperature, $\left.\mathrm{CO}_{2} / \mathrm{CH}_{4}, \mathrm{O}_{2} / \mathrm{CH}_{4}, \mathrm{H}_{2} \mathrm{O} / \mathrm{CH}_{4}\right)$, initial testing of two- and three-variable methods was undertaken to explore the functionality of the method and the relevance of the model outputs. ASPEN Plus v7.3 by AspenTech [48] was used to generate thermodynamic equilibrium data, which was then analysed using MCDM techniques to find the trade-off between costs and benefits and thus identify optimum operating conditions for hydrogen production from biogas (Fig. 1). The overall MCDM technique, consisting of the entropy and TOPSIS methods running in series, was executed via a Matlab code written in-house, interfaced with ASPEN Plus via a local COM automation server (Fig. 1). This choice was taken because the gradient-based optimization routine of ASPEN struggles to determine the solution when there is a large number of decision variables [49]. The Matlab code employed is reported in the supporting information (SI2), while a description of each stage of the process (Fig. 1) is given in the following sections.

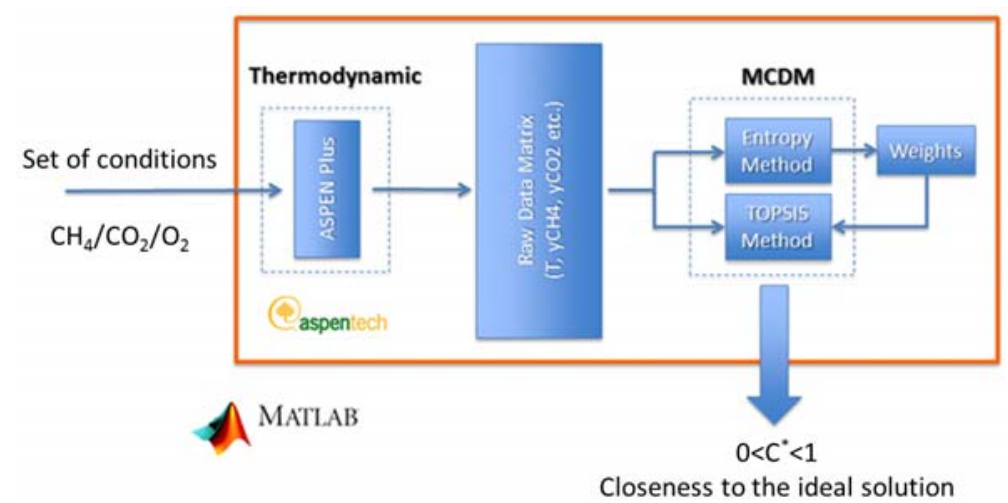

Fig. 1 - Graphical representation of the methodology. The orange box represents the Matlab code, whose inputs and outputs are the set of conditions $\left(\mathrm{CH}_{4} / \mathrm{CO}_{2} / \mathrm{O}_{2}\right)$ and the closeness to the associated ideal solution $\left(C^{*}\right)$, respectively

\subsection{ASPEN Plus simulations}

The thermodynamic data relating to the mixed-reforming of biogas were obtained via ASPEN Plus, using the Peng-Robinson equation of state and the RGibbs block [50], which is based on the minimization of the Gibbs free energy. The model biogas comprised solely of methane and carbon dioxide. The Model Analysis Tool of ASPEN Plus was used to run sensitivity analyses on the temperature inside the reforming reactor. The step sizes chosen for the analysis (Table 2) provide sufficient resolution, with reasonable computational workload. 
The simulations were run at atmospheric pressure, assuming air comprising $79 \% \mathrm{~N}_{2}$ and $21 \%$ $\mathrm{O}_{2}$, while all the heat and mass balances were based on $1 \mathrm{~mol} \mathrm{~s}^{-1}$ of $\mathrm{CH}_{4}$ entering the system.

Regarding the flowsheet used in ASPEN Plus (Fig. 2), biogas with different percentages of methane, water and air (Table 2) enters the reforming block at room temperature and atmospheric pressure. Water is vaporized at $120^{\circ} \mathrm{C}$ in block $\mathrm{HX} 1$, mixed with the other gases in the mixer M1, and fed to the reformer block SRM. Here the reforming takes place at T= $300-1200{ }^{\circ} \mathrm{C}$, with all the components of the simulation considered as possible products (i.e. $\mathrm{CH}_{4}, \mathrm{H}_{2} \mathrm{O}, \mathrm{CO}, \mathrm{H}_{2}, \mathrm{C}$ (graphitic carbon), $\mathrm{CO}_{2}, \mathrm{O}_{2}, \mathrm{~N}_{2}$ ). Even during pure SRM, there are secondary reactions taking place, such as $\mathrm{WGS}, \mathrm{CH}_{4}$ cracking, and $\mathrm{CO}$ disproportionation, the extent of which depends on the availability of reactants and on the temperature inside the block. Endothermic reactions are favoured as temperatures increase, while exothermic reactions are favoured as temperatures decrease. Products and unconverted reactants from the SRM block are assumed to leave the reactor at the reaction temperature.

Table 2 - Conditions for the sensitivity analyses (100\% $\mathrm{CH}_{4}$ in the biogas refers to pure methane)

\begin{tabular}{l|l|l|}
\multicolumn{1}{c}{} & \multicolumn{1}{l}{ Range } & \multicolumn{1}{l}{ Step size } \\
\cline { 2 - 3 } $\mathbf{C H} 4$ in the biogas (\%) & $50-100$ & 10 \\
$\mathbf{T}\left({ }^{\circ} \mathbf{C}\right)$ & $300-1200$ & 5 \\
$\mathbf{H}_{2} \mathbf{O} / \mathbf{C H}_{4}$ & $0-5$ & 0.05 \\
$\mathbf{O}_{2} / \mathbf{C H}_{4}$ & $0-0.5$ & 0.05 \\
\cline { 2 - 3 } & &
\end{tabular}

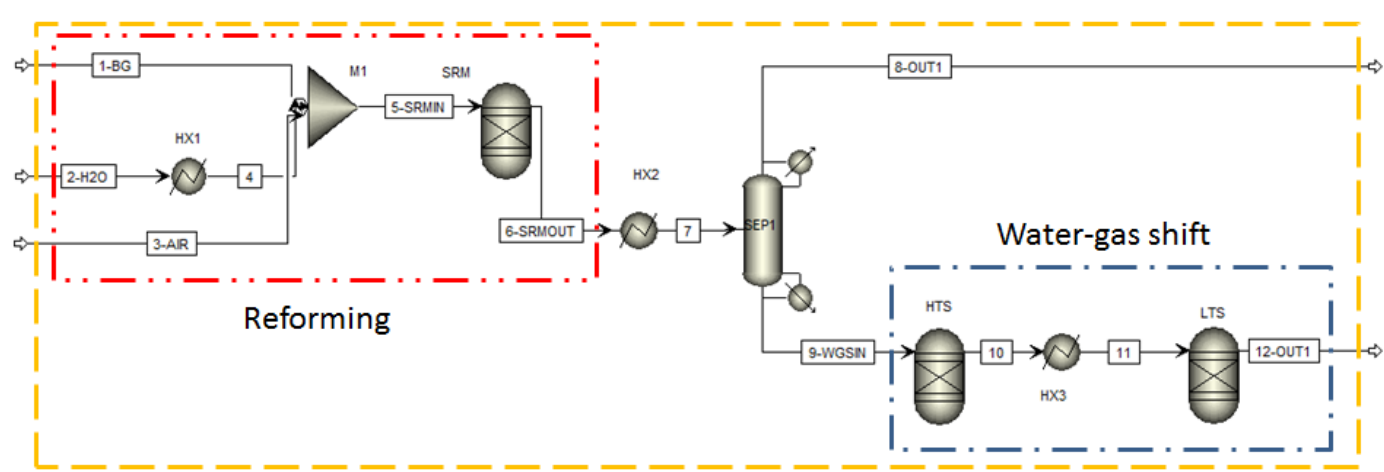

Fig. 2 - ASPEN Plus flow sheet: reformer reactor (SRM), high-temperature shift reactor (HTS), lowtemperature shift reactor (LTS), heat exchangers (HX1, HX2, HX3), mixer (M1), ideal separation block (SEP1). Reforming block (red line, - -), water-gas shift block (blue line, - - -), overall block (yellow line, - - -)

To simulate a process/catalyst which is only selective towards WGS, only $\mathrm{CO}, \mathrm{H}_{2} \mathrm{O}$, $\mathrm{CO}_{2}$, and $\mathrm{H}_{2}$ were allowed as possible products in the HTS and LTS blocks of ASPEN Plus. This is to avoid reverse-SRM and reverse-DRM (both exothermic) which would otherwise happen when the temperature inside the WGS block approaches lower temperature ranges, 
leading to the undesirable formation of $\mathrm{CH}_{4}$ from $\mathrm{CO}$ and $\mathrm{H}_{2}$ [51]. Additionally, the other species were separated in the ideal separator block SEP1 and recovered through line 8. In fact, the simultaneous presence of $\mathrm{CH}_{4}$ and $\mathrm{O}_{2}$ in the equilibrium reactors of the WGS block would lead to the oxidation of unconverted methane, which is exothermic and thermodynamically favoured at any temperature.

The high-temperature shift (HTS) and low-temperature shift (LTS) blocks work at 380 and $225^{\circ} \mathrm{C}$, respectively [6]. The operating conditions of the WGS blocks are fixed, therefore the performance of the overall system is optimized by acting solely on the SRM block variables.

After the WGS stages, the concentration of $\mathrm{CO}$ in real reforming units is usually lower than $1 \%$ [25]. No heat integration is assumed between blocks. The results arising from the thermodynamic modelling of the mixed reforming of biogas in ASPEN Plus are stored in a raw data matrix, before being manipulated into two MCDM techniques in series, namely the entropy [52] and the TOPSIS [53] methods.

\subsection{Entropy method}

The entropy method can be used to determine objective weights or the relative importance of criteria within MCDM problems. The weights are a measurement of the uncertainty in the information (disorder degree) formulated using probability theory, and therefore can be used to evaluate the effectiveness of the information for a particular system. In other words, the method measures the quantity of useful information provided by the data itself [54]. The method is based on entropy as defined by Shannon [55], who demonstrated that a broad distribution is associated with more ambiguity than one with a sharp peak. The greater the entropy weight, the more useful is the information carried by the criterion [56]. Compared with other synthetic evaluation methods for determination of weights, the entropy method shows a decrease in the calculation workload [57].

A MCDM problem can be expressed in a matrix format (Fig. 3): the possible alternatives of the problem, $A_{i}(i=1,2, \ldots, m)$, are reported in the columns, while the criteria or properties, $C_{j}(j=1,2, \ldots, n)$, are shown in the rows. A generic element $x_{i j}$ represents the rating of alternative $i$ with respect to the criterion $j$.

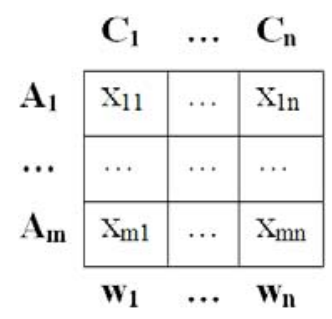


Fig. 3 - Matrix representation of an MCDM problem

The entropy method consists of the following steps:

STEP 1 - Normalize the decision matrix by calculating $\mathrm{p}_{\mathrm{ij}}$ (Equation 9)

$$
p_{i j}=\frac{x_{i j}}{\sum_{i=1}^{m} x_{i j}} \quad i=1,2, \ldots, m ; j=1,2, \ldots, n \quad \text { Equation } 9
$$

Raw data are normalized to eliminate anomalies with different measurement units and scales.

STEP 2 - Compute the entropy $h_{j}$ (Equation 10). The constant $\lambda$ (Equation 11) guarantees that $0 \leq h_{j} \leq 1$, assuming that when when $p_{i j}=0, \ln \left(p_{i j}\right)=0$.

$$
\begin{array}{cr}
h_{j}=-\lambda \sum_{i=1}^{m} p_{i j} \ln \left(p_{i j}\right) \quad i=1,2, \ldots, m ; j=1,2, \ldots, n & \text { Equation 10 } \\
\lambda=1 / \ln (m) & \text { Equation 11 }
\end{array}
$$

STEP 3 - Calculate the degree of diversification of the average information contained in each criterion, $\mathrm{d}_{\mathrm{j}}$ (Equation 12)

$$
d_{j}=1-h_{j} \quad j=1,2, \ldots, n \quad \text { Equation } 12
$$

STEP 4 - Determine the degree of importance (weight of entropy) of criterion $\mathrm{j}, \mathrm{w}_{\mathrm{j}}$ (Equation 13, Equation 14)

$$
\begin{array}{cc}
w_{j}=\frac{d_{j}}{\sum_{s=1}^{n} d_{s}} \quad j=1,2, \ldots, n & \text { Equation 13 } \\
\sum_{j=1}^{n} w_{j}=1 & \text { Equation 14 }
\end{array}
$$

\subsection{TOPSIS method}

The TOPSIS method is a goal-based decision-making technique which needs information about the criterion weights in order to find which alternative is as close as possible to the positive-ideal solution (PIS), which is where all the benefit criteria are maximized and all the costs are minimized simultaneously. The negative-ideal solution (NIS) occurs when benefits are minimized and costs maximized. The distance between an alternative and the PIS is called closeness to the positive-ideal solution $\left(C^{*}\right)$, and it varies from 0 to 1 when the alternative corresponds to the NIS or PIS, respectively (Fig. 4) [53]; a $C^{*}$ value equal to 0 or 1 is an ideal case, and never happens in reality. The TOPSIS method is one of the most famous MCDM techniques, and its main advantages are: it is rational and understandable; the computational steps are straightforward; and the weights are incorporated into the comparison procedure. The steps in the TOPSIS method are shown in the supporting information, SI1. 


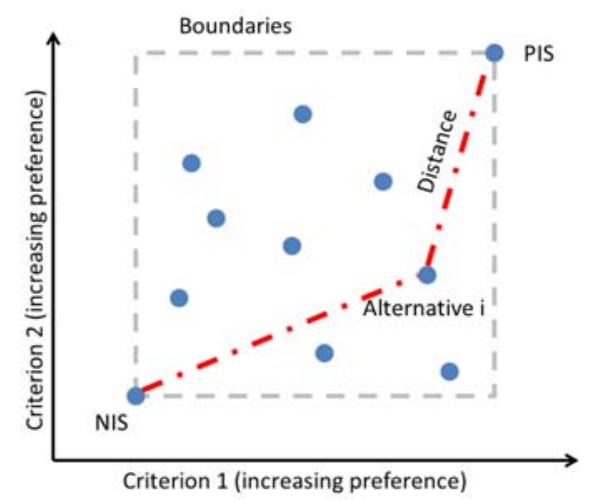

Fig. 4 - Illustration of the TOPSIS method with two variables. The grey dashed line (- - -) indicates the criteria boundaries, while the red dashed and dotted line (- -) indicates the distance between alternative $i$ and the ideal solutions (NIS and PIS)

\subsection{Running the simulation}

The percentages of $\mathrm{CH}_{4}, \mathrm{CO}_{2}$ and air entering the block diagram (Fig. 2) were fixed. The conversion of methane in the reformer (Equation 15) and total yield of hydrogen (Equation 16) were set as benefits, while the total yield of coke (Equation 17) and the net energy requirement for the process (Equation 18) were set as costs. The net energy requirement is the sum of the energy required or released by the blocks indicated as $\operatorname{SRM}(\mathrm{kW})$, HTS $(\mathrm{kW})$, LTS(kW), HX1(kW), HX2(kW) and HX3(kW) (Fig. 2).

Methane conversion in the reformer was maximized because (i) it is the main reactant, (ii) it is a GHG (flaring should to be avoided), and (iii) a low methane slip is often crucial for the economics of the process [6]. The total yield of hydrogen (Equation 16) was maximized because it represents the main product of the process and because hydrogen loss in the form of unconverted steam at the outlet of the system represents an exergy loss [58]. The total yield of coke (Equation 17) was set as a cost, because coke is highly detrimental to the catalyst and inhibits the reforming and oxidation reactions that lead to the production of hydrogen. Finally, the net energy input was minimized in order to maximize the thermal efficiency of the simulation, as poor process performance could arise from underutilized heat outputs [59]. It was assumed that there were no heat losses between a given block and the following one in the block diagram. Selectivity towards a certain species, which is the combination of the yield of that species and methane conversion, was not included in the analysis to avoid redundancy between criteria.

The ASPEN Plus simulation was run, considering two sensitivity analyses: one on the $\mathrm{H}_{2} \mathrm{O} / \mathrm{CH}_{4}$ ratio of the feed stream, and the other on the temperature of the SRM block (Table 2). The equilibrium data were generated and then stored in a matrix before being processed in the MCDM block. As the equilibrium data only depend on the operating conditions (i.e. 
temperature and feed ratios), the only degree of freedom left to influence the analysis, without modifying the flow sheet, is the choice of cost and benefit criteria. The raw data distributions were used in the entropy method to generate the objective weights, which in turn were used in the TOPSIS method to rank the different operating conditions according to the $C^{*}$ values. The steps were then repeated considering biogas with different concentrations of $\mathrm{CO}_{2}$ and air at the inlet (Table 2). The model was verified and debugged as described in the supporting information, SI2.

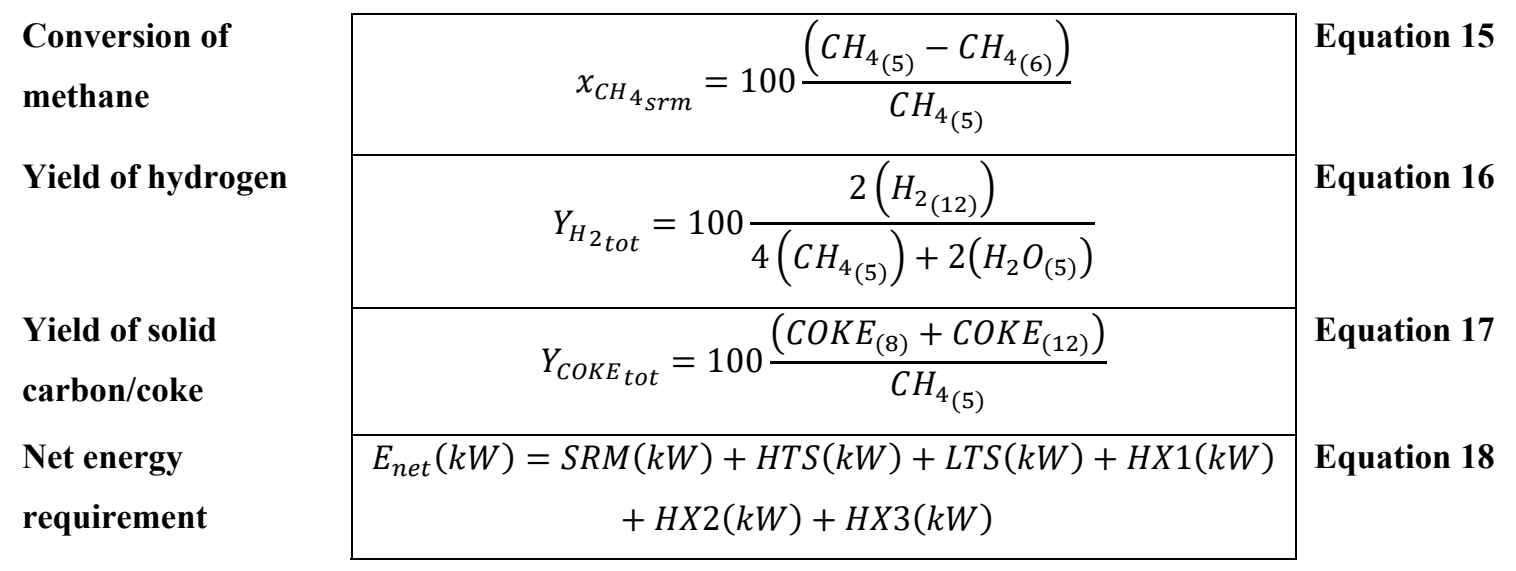

\section{Results}

\subsection{Two-variable MCDM}

The two variables considered were $\mathrm{T}\left({ }^{\circ} \mathrm{C}\right)$ and $\mathrm{H}_{2} \mathrm{O} / \mathrm{CH}_{4}$. The composition of the biogas and the $\mathrm{O}_{2} / \mathrm{CH}_{4}$ ratio were fixed. The method found the optimal operating temperature at different values of $\mathrm{H}_{2} \mathrm{O} / \mathrm{CH}_{4}$. For instance, when pure methane and no air were present in the feed, the method calculated a recommended temperature of $775^{\circ} \mathrm{C}$ and a $\mathrm{H}_{2} \mathrm{O} / \mathrm{CH}_{4}$ ratio of 1.5 (Table 3). By working at these operating conditions during steam reforming of pure methane, the equilibrium composition of the product stream comprised around $78 \% \mathrm{H}_{2}$ and had a $\mathrm{H}_{2} / \mathrm{CO}$ ratio equal to 7.4, without any coke deposition (Fig. 5), although methane conversion was not complete $(\sim 96.7 \%)$ and the reaction was more endothermic than pure SRM with a stoichiometric feed (274 vs. $\left.208 \mathrm{~kJ} \mathrm{~s}^{-1}\right)$. The results correspond well with other findings in the literature ([25], Table 1), demonstrating the functionality of the method.

Table 3 - Optimal outcome for the criteria of interest, when running the two-variable MCDM method with pure methane as the feed. $\mathrm{CH}_{4} / \mathrm{CO}_{2} / \mathrm{O}_{2}=1 / 0 / 0, \mathrm{C}_{\max }^{*}=0.9985, \mathrm{~T}_{\text {optimal }}=775{ }^{\circ} \mathrm{C}, \mathrm{H}_{2} \mathrm{O} / \mathrm{CH}_{40 p t i m a l}=$

1.5

\begin{tabular}{|c|c|c|c|c|}
\hline & $\boldsymbol{x}_{\boldsymbol{C H}_{\mathbf{4}_{\text {srm }}}}(\%)$ & $\boldsymbol{Y}_{\boldsymbol{H}_{2 t o t}}(\%)$ & $Y_{\text {COKE }}$ tot $(\%)$ & $E_{n e t}(k W)$ \\
\hline $\mathrm{CH}_{4}$ in the biogas $(\%)$ & \multicolumn{4}{|c|}{$\mathrm{O}_{2} / \mathrm{CH}_{4}=\mathbf{0}$} \\
\hline 100 & 96.72 & 97.37 & 0.00 & 274.57 \\
\hline
\end{tabular}




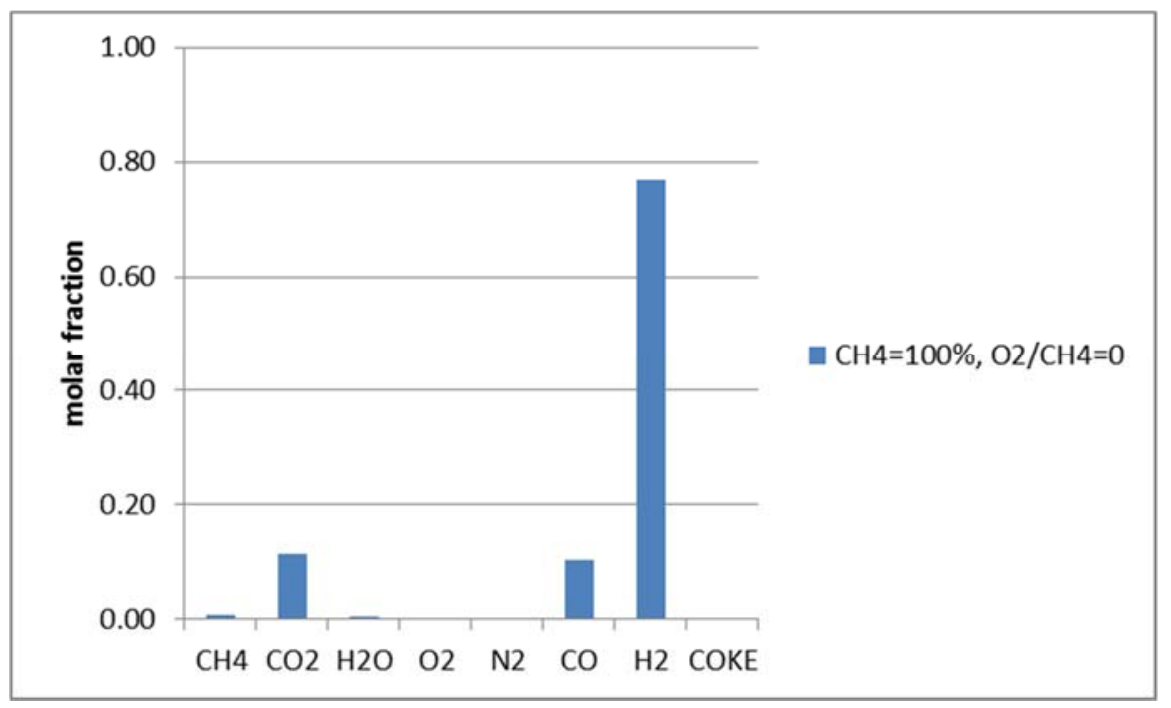

Fig. 5 - Molar fractions of the final stream, when running the two-variable MCDM method with pure methane as the feed. $\mathrm{CH}_{4} / \mathrm{CO}_{2} / \mathrm{O}_{2}=1 / 0 / 0, \mathrm{C}_{\max }^{*}=0.9985, \mathrm{~T}_{\text {optimal }}=775^{\circ} \mathrm{C}, \mathrm{H}_{2} \mathrm{O} / \mathrm{CH}_{40 p t i m a l}=1.5$

\subsection{Three-variable MCDM}

The two-variable analysis was extended to three dimensions with $\mathrm{T}\left({ }^{\circ} \mathrm{C}\right), \mathrm{H}_{2} \mathrm{O} / \mathrm{CH}_{4}$, and $\mathrm{O}_{2} / \mathrm{CH}_{4}$ as variables, by keeping $\mathrm{CO}_{2} / \mathrm{CH}_{4}$ constant while running a sensitivity analysis on the air concentration in the feed. Initially the $\mathrm{CO}_{2} / \mathrm{CH}_{4}$ ratio was fixed at 0 (pure methane in the feed), and the highest value for $C^{*}(0.9988)$ obtained at $735{ }^{\circ} \mathrm{C}$, with $\mathrm{O}_{2} / \mathrm{CH}_{4}=0.05$ and $\mathrm{H}_{2} \mathrm{O} / \mathrm{CH}_{4}=1.45$ (Fig. 6). When considering pure methane, increasing the amount of air in the feed caused a decrease in both the optimal operating temperature for the reformer and the optimal $\mathrm{H}_{2} \mathrm{O} / \mathrm{CH}_{4}$ ratio. The $C^{*}$ values were not drastically affected (standard deviation equal to 0.004 ), because the decrease in the conversion of methane and in the yield of hydrogen with an increasing amount of air in the feed were compensated by the lower net heat required by the process; from $\mathrm{O}_{2} / \mathrm{CH}_{4}=0.35$ upwards, the $E_{\text {net }}(k W)$ value was negative (i.e. the overall process becomes exothermic) (Fig. 7).

At each optimal operating condition the carbon yield was zero, reflecting the fact that the minimization of solid carbon formation was the highest weighted criterion in the simulation (Fig. 9). The molar fractions of $\mathrm{CO}$ and $\mathrm{H}_{2}$ decreased with increasing $\mathrm{O}_{2} / \mathrm{CH}_{4}$ ratio, to a certain extent because the $\mathrm{CO}$ and $\mathrm{H}_{2}$ were oxidized to produce thermal energy, but also because there was an increasing amount of inert $\mathrm{N}_{2}$ in the system coming from air, which diluted the product stream (Fig. 8). In the optimal case of $\mathrm{O}_{2} / \mathrm{CH}_{4}=0.05$, the final product stream contained $73 \%$ $\mathrm{H}_{2}, 13 \% \mathrm{CO}_{2}, 8 \% \mathrm{CO}, 4 \% \mathrm{~N}_{2}, 1 \% \mathrm{CH}_{4}$ and $1 \% \mathrm{H}_{2} \mathrm{O}$. No solid carbon was deposited, and the $\mathrm{O}_{2}$ in the feed was completely converted in all the alternative process conditions (Fig. 6), because it was always present in sub-stoichiometric amounts. Carbon dioxide was always 
present in the final stream (8-15\%), with excess steam up to around $30 \%$ at higher $\mathrm{O}_{2} / \mathrm{CH}_{4}$ values due to the oxidation reactions taking place.

The results show similar trends to those in the literature when different boundaries are taken into account. For example, in an analysis that considered a narrower range of steam-tomethane ratio (0-1.2), Seo et al [25] recommended a higher temperature and $\mathrm{O}_{2} / \mathrm{CH}_{4}$ ratio (800 vs. $735^{\circ} \mathrm{C}, 0.58$ vs. 0.05 , in [25] and this paper respectively), which were needed to compensate for the lower steam-to-carbon ratio (0.35 vs. 1.45$)$.

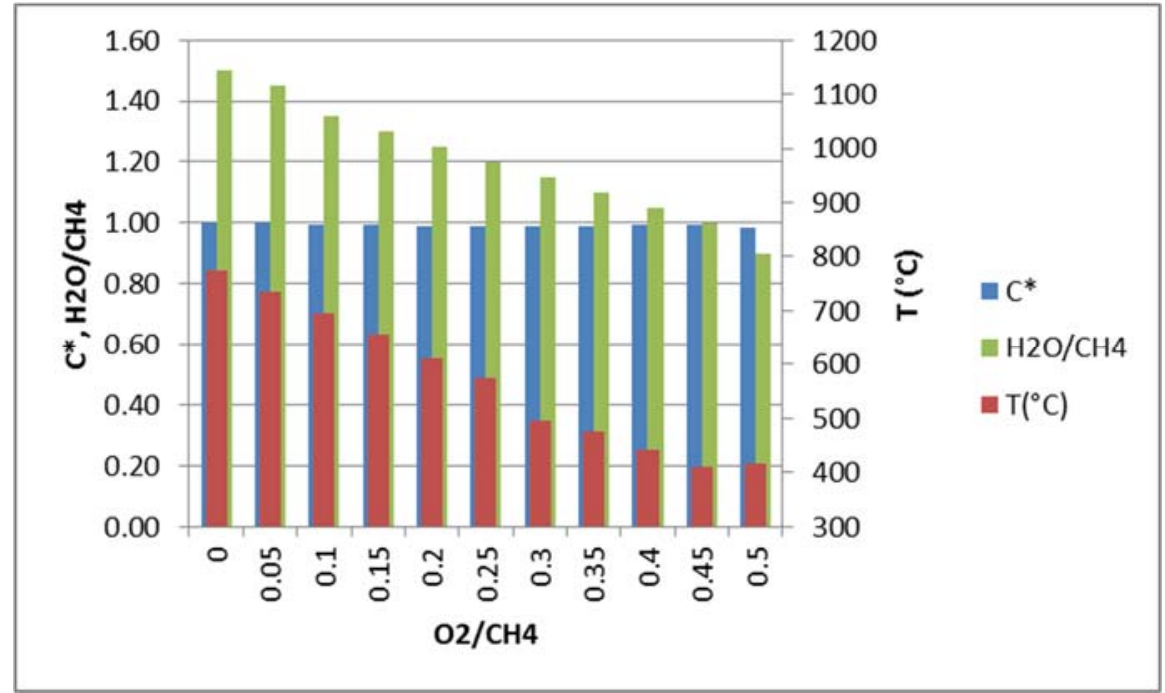

Fig. 6 - Optimal operating conditions, when running the three-variable MCDM method with pure methane as the feed. $\mathrm{CH}_{4} / \mathrm{CO}_{2}=1 / 0, \mathrm{C}^{*}{ }_{\text {max }}=0.9988, \mathrm{~T}_{\text {optimal }}=735^{\circ} \mathrm{C}, \mathrm{O}_{2} / \mathrm{CH}_{40 p t i m a l}=0.05, \mathrm{H}_{2} \mathrm{O} / \mathrm{CH}_{40 p t i m a l}$ $=1.45$

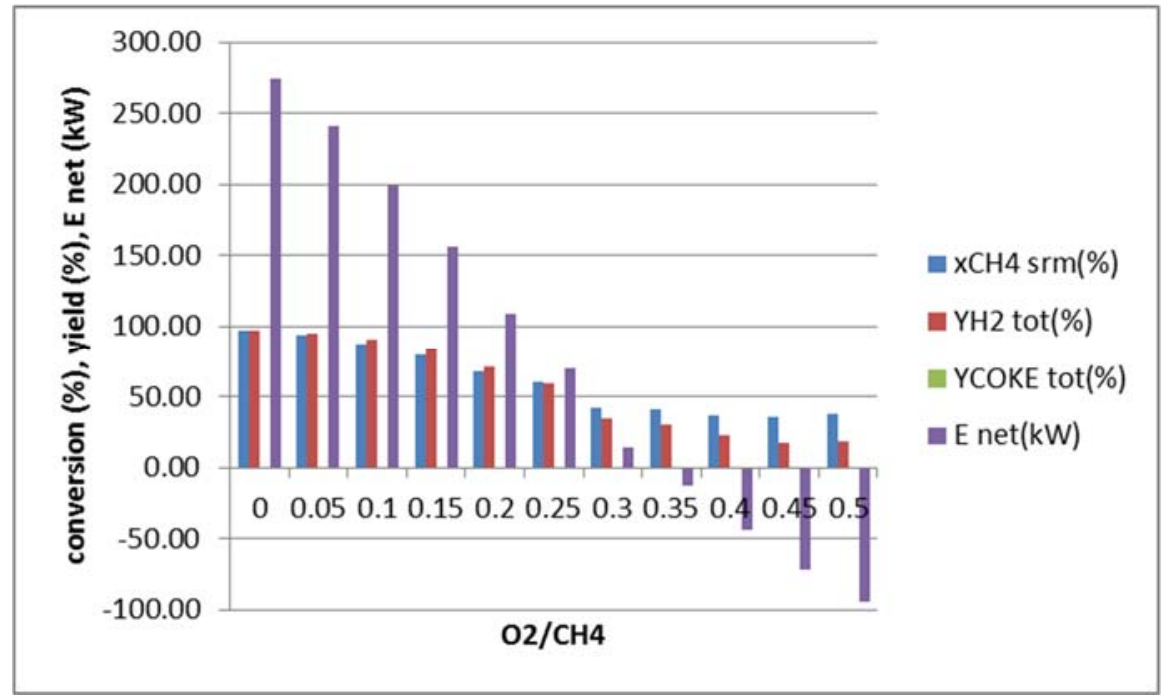

Fig. 7 - Optimal outcome for the criteria of interest, when running the three-variable MCDM method with pure methane as the feed. $\mathrm{CH}_{4} / \mathrm{CO}_{2}=1 / 0, \mathrm{C}^{*}$ max $=0.9988, \mathrm{~T}_{\text {optimal }}=735^{\circ} \mathrm{C}, \mathrm{O}_{2} / \mathrm{CH}_{4 \text { optimal }}=0.05$, $\mathrm{H}_{2} \mathrm{O} / \mathrm{CH}_{4}$ optimal $=1.45$ 


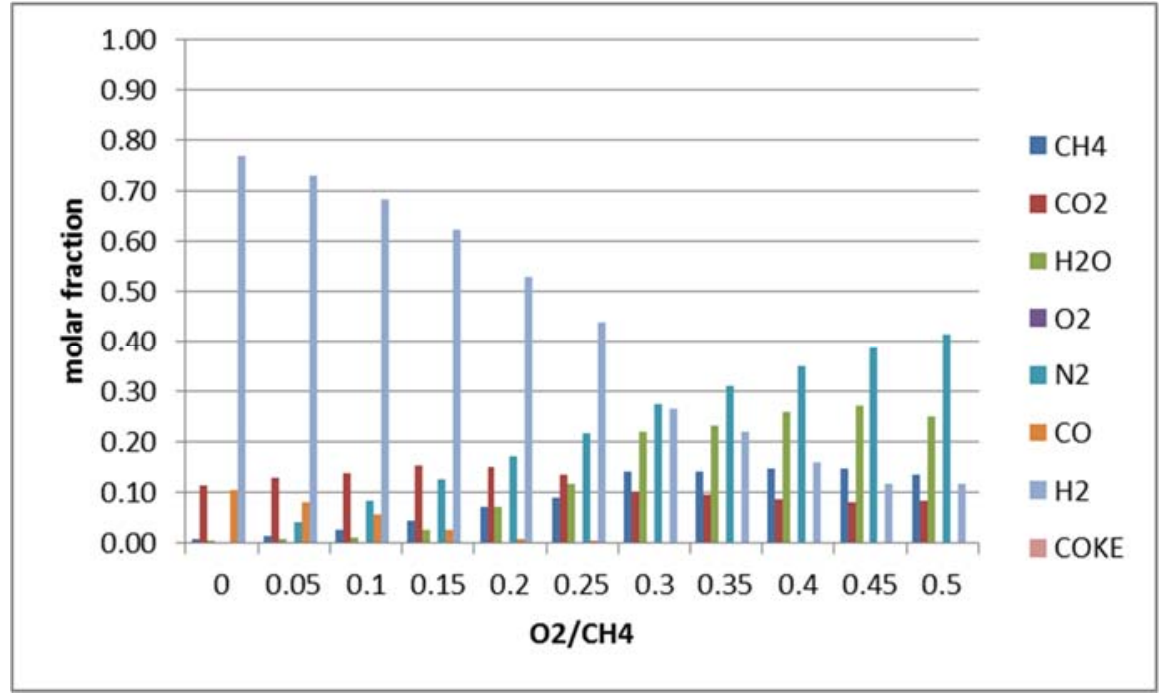

Fig. 8 - Molar fractions of the final stream, when running the three-variable MCDM method with pure methane as the feed. $\mathrm{CH}_{4} / \mathrm{CO}_{2}=1 / 0, \mathrm{C}^{*}{ }_{\text {max }}=0.9988, \mathrm{~T}_{\text {optimal }}=735{ }^{\circ} \mathrm{C}, \mathrm{O}_{2} / \mathrm{CH}_{4 \text { optimal }}=0.05, \mathrm{H}_{2} \mathrm{O} / \mathrm{CH}_{4 \text { optimal }}$ $=1.45$

\subsection{Four-variable MCDM model for optimisation of mixed reforming of biogas}

The full results of the MCDM methodology with four variables (supporting information SI3, with a sample plot for $\mathrm{CH}_{4}=50 \%$ in Fig. 10 ) were obtained considering $\mathrm{T}\left({ }^{\circ} \mathrm{C}\right), \mathrm{H}_{2} \mathrm{O} / \mathrm{CH}_{4}$, $\mathrm{O}_{2} / \mathrm{CH}_{4}$, and $\mathrm{CO}_{2} / \mathrm{CH}_{4}$ as variables (Table 4 ). The weights for the criteria from the entropy method at different biogas compositions are shown in Fig. 9.

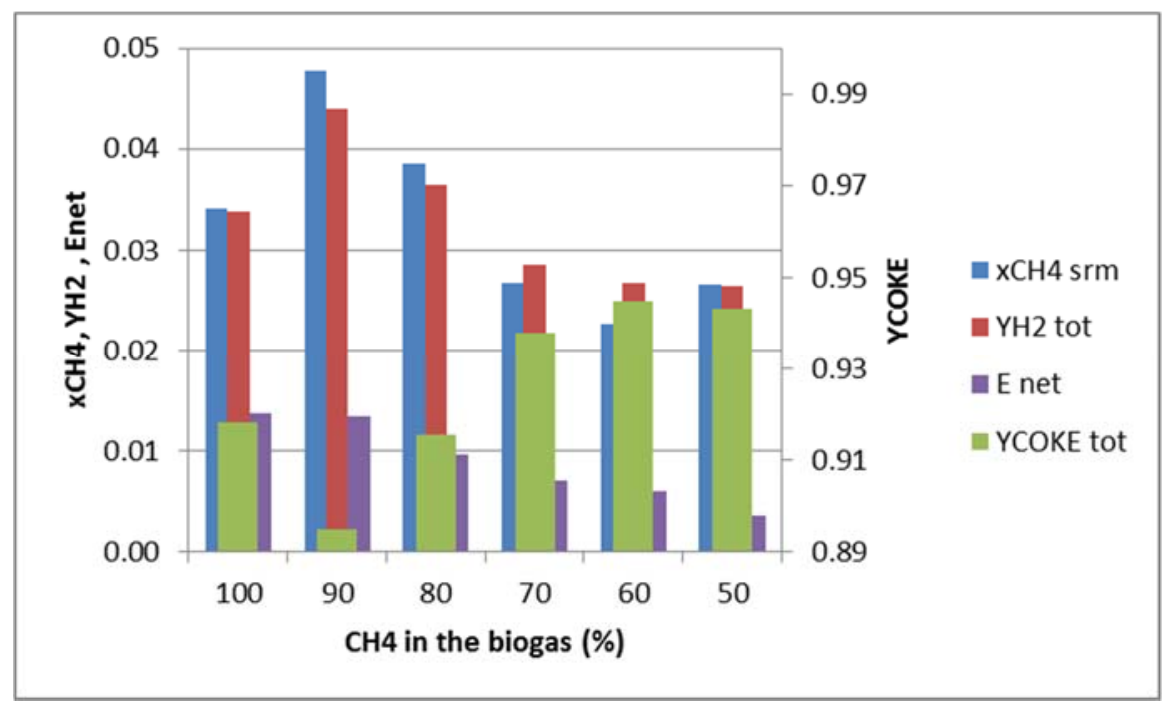

Fig. 9 - Weights for the criteria evaluated via the entropy method at different values of methane concentration in the biogas

When the percentage of methane in the biogas was $60-70 \%$, the method suggested running tri-reforming at $735-750{ }^{\circ} \mathrm{C}$; a combination of dry and steam reforming at a higher temperature was preferred when the methane concentration in the biogas was 50, 80, and 90 $\%$. In the case of pure methane, the best route is to couple steam reforming and partial oxidation, resulting in the lowest $\mathrm{H}_{2} \mathrm{O} / \mathrm{CH}_{4}$ operating value; the optimal steam-to-methane ratio 
suggested by the method increased almost exponentially with increasing concentration of carbon dioxide in the biogas.

When working at the optimal conditions suggested by the method, the conversion of methane increases by $6.5 \%$ with the percentage of carbon dioxide in the biogas going from 0 to $50 \%$ (Table 5). The hydrogen yield first reached its peak at $\mathrm{CH}_{4}=90 \%$ and then decreased with the increase of $\mathrm{CO}_{2}$ in the biogas (because methane is the source of hydrogen). When using pure methane, the hydrogen yield was slightly lower than that obtained when using biogas with $\mathrm{CH}_{4}=80-90 \%$, because the $\mathrm{O}_{2} / \mathrm{CH}_{4}$ ratio of 0.05 in the feed leads to the combustion of a small percentage of the hydrogen previously produced (Table 4). Because minimization of coke yield was the most important criterion in all the options analysed (Fig. 9), there was no solid carbon formation for any of the operating condition suggested by the method. The net energy requirement was minimal when using pure methane and oxygen in the feed, because (i) of the oxidation reactions occurring, (ii) it had the lowest steam-to-carbon ratio of all options (meaning less heat was required to vaporize the water), and (iii) there was no $\mathrm{CO}_{2}$ in the feed (resulting in no DRM and a less endothermic overall reaction).

With an increasing concentration of $\mathrm{CH}_{4}$ in the biogas, the hydrogen and carbon monoxide concentrations on a wet basis increased from 56 to $75 \%$, and 1 to $8 \%$, respectively (Fig. 11). On a dry basis, the hydrogen molar fraction was relatively constant at $70 \pm 5 \%$ for the different feed conditions, showing that biogas can be a valid substitute for methane in the reforming process.

Table 4 - Optimal operating conditions, when running the four-variable MCDM method. $\mathrm{C}^{*} \max =$ 0.9999, $\mathrm{T}_{\text {optimal }}=790{ }^{\circ} \mathrm{C}, \mathrm{CH}_{4} / \mathrm{CO}_{2} / \mathrm{O}_{2} / \mathrm{H}_{2} \mathrm{O}_{\text {optimal }}=1 / 1 / 0 / 3$

\begin{tabular}{|c|c|c|c|c|}
\hline $\mathrm{CH}_{4}(\%)$ in the biogas & $T\left({ }^{\circ} \mathrm{C}\right)_{\text {optimal }}$ & $\mathrm{O}_{2} / \mathrm{CH}_{4}$ optimal & $\mathrm{H}_{2} \mathrm{O} / \mathrm{CH}_{4}$ optimal & $C_{\max }^{*}$ \\
\hline 100 & 735 & 0.05 & 1.45 & 0.9988 \\
\hline 90 & 770 & 0 & 1.6 & 0.9983 \\
\hline 80 & 765 & 0 & 1.75 & 0.9992 \\
\hline 70 & 750 & 0.05 & 2 & 0.9996 \\
\hline 60 & 735 & 0.1 & 2.4 & 0.9997 \\
\hline 50 & 790 & 0 & 3 & 0.9999 \\
\hline
\end{tabular}



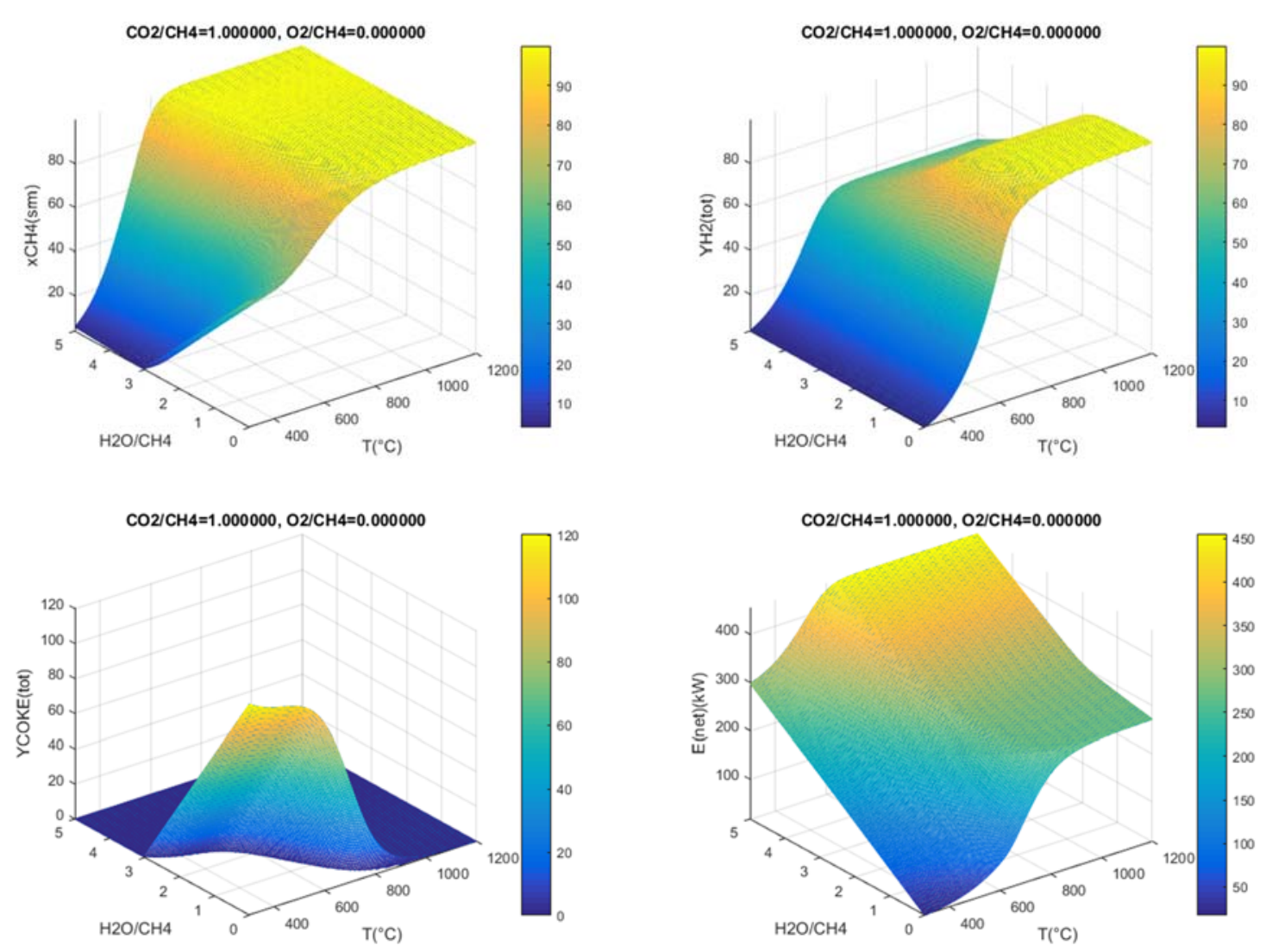

Fig. 10 - Distributions for the criteria at different values of temperature and $\mathrm{H}_{2} \mathrm{O} / \mathrm{CH}_{4}$, when running the four-variable MCDM method. $\mathrm{CH}_{4} / \mathrm{CO}_{2} / \mathrm{O}_{2}=1 / 1 / 0, \mathrm{C}^{*}{ }_{\text {optimal }}=0.9999, \mathrm{~T}_{\text {optimal }}=790{ }^{\circ} \mathrm{C}$,

$\mathrm{H}_{2} \mathrm{O} / \mathrm{CH}_{40 p t i m a l}=3$

Table 5 - Optimal outcome for the criteria of interest, when running the four-variable MCDM method.

$$
\mathrm{C}_{\max }^{*}=0.9999, \mathrm{~T}_{\text {optimal }}=790{ }^{\circ} \mathrm{C}, \mathrm{CH}_{4} / \mathrm{CO}_{2} / \mathrm{O}_{2} / \mathrm{H}_{2} \mathrm{O}_{\text {optimal }}=1 / 1 / 0 / 3
$$

\begin{tabular}{|c|c|c|c|c|}
\hline $\mathrm{CH}_{4}$ in the biogas $(\%)$ & $\boldsymbol{x}_{\boldsymbol{C H}_{\mathbf{4}_{\text {srm }}}}(\%)$ & $\boldsymbol{Y}_{\boldsymbol{H}_{2_{\text {tot }}}}(\%)$ & $Y_{\text {COKE }_{\text {tot }}}(\%)$ & $E_{n e t}(k W)$ \\
\hline 100 & 93.73 & 95.30 & 0.00 & 240.90 \\
\hline 90 & 97.41 & 97.35 & 0.00 & 279.19 \\
\hline 80 & 98.03 & 96.77 & 0.00 & 285.33 \\
\hline 70 & 98.57 & 92.83 & 0.00 & 272.33 \\
\hline 60 & 98.98 & 84.06 & 0.00 & 271.26 \\
\hline 50 & 99.80 & 78.82 & 0.00 & 350.86 \\
\hline
\end{tabular}




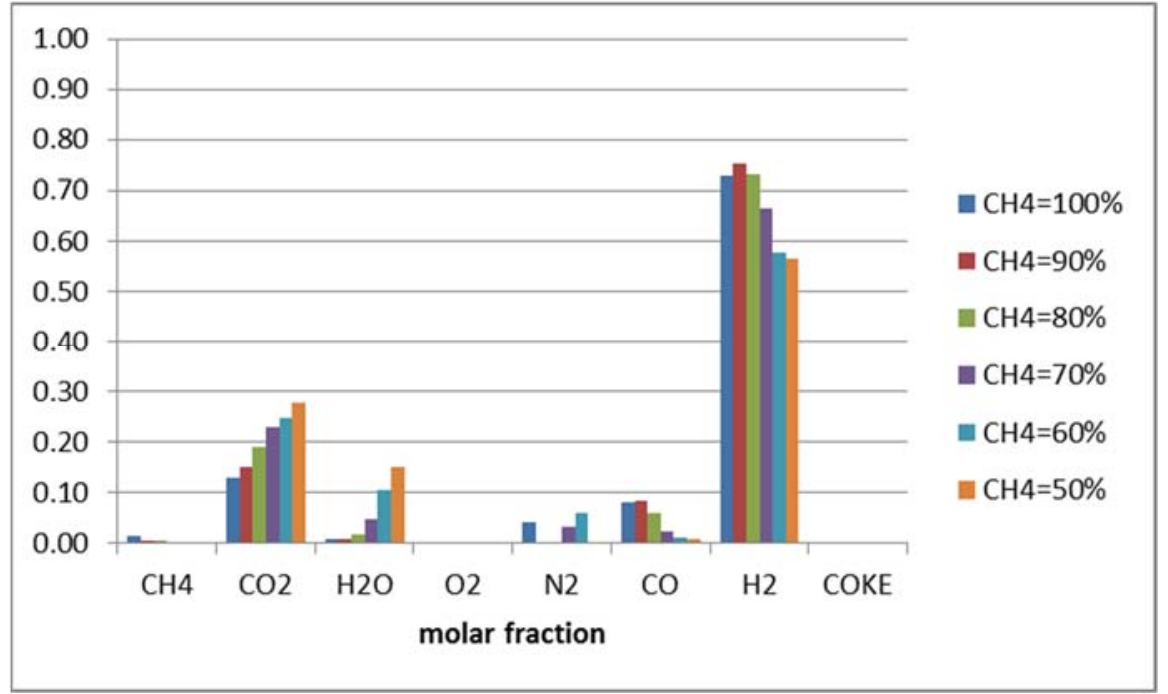

Fig. 11 - Molar fractions of the final stream on a wet basis, when running the four-variable MCDM method. $\mathrm{C}_{\max }^{*}=0.9999, \mathrm{~T}_{\text {optimal }}=790{ }^{\circ} \mathrm{C}, \mathrm{CH}_{4} / \mathrm{CO}_{2} / \mathrm{O}_{2} / \mathrm{H}_{2} \mathrm{O}_{\text {optimal }}=1 / 1 / 0 / 3$

\section{Discussion of results}

The results compare reasonably well with the literature when the trade-off between temperature and steam- and/or air-to-methane ratio is considered (Table 6). The method recommended a low $(<2.5)$ steam-to-methane ratio for all reforming processes. Although SRM is the most economical way to produce hydrogen, around $37 \%$ of the exergy is not utilized and around $10 \%$ is wasted in the exhaust stream [58]. Usually a high steam-to-methane ratio is advised during SRM [6], because it favours methane conversion, increases the production of $\mathrm{H}_{2}$ via WGS, and inhibits the formation of carbon deposits on the catalyst [60]. However, a ratio below 2.5 would reduce the mass flow through the plant, decrease the size of the equipment and the operating costs [61], keep the formation of $\mathrm{CO}_{2}$ in the WGS reaction low [62], and minimize the energy required to vaporize water $[24,61,63,64]$.

The optimal scenario for maximum syngas production with minimal energy expenditure and solid carbon deposition (biogas with 50-60\% $\mathrm{CH}_{4}$, and reforming operating conditions of $\mathrm{CH}_{4} / \mathrm{CO}_{2} / \mathrm{O}_{2} / \mathrm{H}_{2} \mathrm{O}=1 / 0.67-1 / 0.1-0 / 2.4-3$ and $735-790{ }^{\circ} \mathrm{C}$ (Table 4)) relates well to existing practices in both the reforming and $\mathrm{AD}$ industries. At the optimal operating conditions, the final concentration of $\mathrm{CO}$ in the output stream is slightly lower than $1 \%$, which is the average target for hydrogen-rich streams produced in industrial reforming processes [25]. Biogas composition of $50-60 \%$ is typical in operational AD plants $[16,65]$. The results recommend minimizing the net energy required in order to have a more favourable process. As a consequence of the low-temperature conditions recommended, catalysts with higher resistance to carbon deposition would be required during real operation $[65,66]$.

Table 6 - Comparison of the optimal values between literature and this article (in parentheses) 


\begin{tabular}{|c|c|c|c|c|}
\hline $\mathrm{CH}_{4}$ in the biogas (\%) & $T\left({ }^{\circ} \mathrm{C}\right)_{\text {optimal }}$ & $\mathrm{O}_{2} / \mathrm{CH}_{4_{\text {optimal }}}$ & $\mathrm{H}_{2} \mathrm{O} / \mathrm{CH}_{4}$ optimal & Ref \\
\hline 50 & $850(790)$ & $0(0)$ & $2(3)$ & [43] \\
\hline 60 & $750(735)$ & $0(0.1)$ & $2.5(2.4)$ & [29] \\
\hline 100 & $800(735)$ & $0(0.05)$ & $1.9(1.45)$ & {$[25]$} \\
\hline
\end{tabular}

The developed method is based on thermodynamic data and represents the ideal scenario. A low $\mathrm{O}_{2} / \mathrm{CH}_{4}$ is always recommended; if oxygen is present above the stoichiometric value in the feed, $\mathrm{CO}_{2}$ and $\mathrm{H}_{2} \mathrm{O}$ formation via total oxidation is favoured over partial oxidation, causing loss of $\mathrm{CO}$ and $\mathrm{H}_{2}$. A methodology based on a kinetic model consider the actual catalyst selectivity towards partial or total oxidation, hence exploring a larger range of $\mathrm{O}_{2} / \mathrm{CH}_{4}$ ratio. However, kinetic models often apply to narrow ranges of operating conditions, and are catalyst or reaction environment specific. Therefore the optimal operating conditions based on thermodynamics in this model are adequately realistic and provide the basis for experimental catalysis research. The model could be improved by including the furnace used to maintain the reformer temperature, and considering heat integration and actual heat losses between blocks.

\section{Conclusions}

The aim of this paper was to develop a clear and comprehensive methodology to consider various compositions of biogas, combinations of reactions, and process conditions in order to make recommendations for optimizing the operating conditions of mixed reforming of methane/biogas. The outcome of this paper is quite powerful, because it considers (i) the reforming of methane/biogas with different compositions, (ii) the possible combinations of reactions obtained by adding air and/or steam to the feed, (iii) a wide range of operating conditions with reasonably small step sizes, and (iv) the simultaneous optimization of four criteria (methane conversion, hydrogen yield, carbon yield, energy requirement). The analysis showed that the optimal way to convert pure methane into hydrogen is at $735^{\circ} \mathrm{C}$, with $\mathrm{O}_{2} / \mathrm{CH}_{4}$ and $\mathrm{H}_{2} \mathrm{O} / \mathrm{CH}_{4}$ equal to 0.05 and 1.45 , respectively. For biogas, the ideal case is $\mathrm{CH}_{4}$ of 50-60 $\%$, with reforming reactor conditions at $\mathrm{T}=790-735{ }^{\circ} \mathrm{C}, \mathrm{O}_{2} / \mathrm{CH}_{4}=0-0.1$ and $\mathrm{H}_{2} \mathrm{O} / \mathrm{CH}_{4}=3-2.4$. The method shows that biogas can theoretically be exploited to produce hydrogen as efficiently as methane/natural gas over an effective range of operating conditions. The research also developed a novel methodology where two MCDM techniques in series were used to optimize the operating conditions for a chemical reaction network. The method is based on thermodynamics, requires low computational workload, can maximize or minimize several criteria simultaneously, and is transferable to different scenarios for the optimization of 
complicated networks. The results represent a starting point for experimental research on catalysts at the identified optimal operating conditions.

\section{Acknowledgements}

This work was completed as part of the ATBEST (Advanced Technologies for Biogas Efficiency, Sustainability and Transport) Marie-Curie Initial Training Network. The network has received funding from the European Union's Seventh Framework Programme for research, technological development and demonstration under grant agreement no. 316838. ATBEST is coordinated by the QUESTOR Centre at Queen's University Belfast (www.atbest.eu).

\section{Supporting information}

Please refer to the supplementary data associated with this article. 


\section{References}

[1] Thomas CE, James BD, Lomax Jr FD, Kuhn Jr IF. Fuel options for the fuel cell vehicle: hydrogen, methanol or gasoline? International Journal of Hydrogen Energy. 2000;25(6):551-67.

[2] Alves HJ, Bley Junior C, Niklevicz RR, Frigo EP, Frigo MS, Coimbra-Araújo CH. Overview of hydrogen production technologies from biogas and the applications in fuel cells. International Journal of Hydrogen Energy. 2013;38(13):5215-25.

[3] Tseng P, Lee J, Friley P. A hydrogen economy: opportunities and challenges. Energy. 2005;30(14):2703-20.

[4] M. C. Annesini VP, L. Turchetti. Carbon Formation in the Steam Reforming Process: a Thermodynamic Analysis Based on the Elemental Composition. Chemical Engineering Transaction. 2007;11:6.

[5] LeValley TL, Richard AR, Fan M. The progress in water gas shift and steam reforming hydrogen production technologies - A review. International Journal of Hydrogen Energy. 2014;39(30):169837000 .

[6] Moulijn JA, Makkee M, Diepen AEv. Chapter 5 - Production of Synthesis gas. In: Wiley, editor. Chemical Process Technology, 2nd Edition: Wiley; 2013. p. 566.

[7] Izquierdo U, Barrio VL, Lago N, Requies J, Cambra JF, Güemez MB, et al. Biogas steam and oxidative reforming processes for synthesis gas and hydrogen production in conventional and microreactor reaction systems. International Journal of Hydrogen Energy. 2012;37(18):13829-42.

[8] Pino L, Vita A, Laganà $M$, Recupero V. Hydrogen from biogas: Catalytic tri-reforming process with $\mathrm{Ni} / \mathrm{LaCeO}$ mixed oxides. Applied Catalysis B: Environmental. 2014;148-149:91-105.

[9] Braga LB, Silveira JL, da Silva ME, Tuna CE, Machin EB, Pedroso DT. Hydrogen production by biogas steam reforming: A technical, economic and ecological analysis. Renewable and Sustainable Energy Reviews. 2013;28:166-73.

[10] Avraam DG, Halkides TI, Liguras DK, Bereketidou OA, Goula MA. An experimental and theoretical approach for the biogas steam reforming reaction. International Journal of Hydrogen Energy. 2010;35(18):9818-27.

[11] Manenti F, Pelosato R, Vallevi P, Leon-Garzon AR, Dotelli G, Vita A, et al. Biogas-fed solid oxide fuel cell (SOFC) coupled to tri-reforming process: Modelling and simulation. International Journal of Hydrogen Energy. 2015;40(42):14640-50.

[12] Ireland SEAo. Assessment of Costs and Benefits of Biogas and Biomethane in Ireland. 2017.

[13] Kalt G, Kranzl L. Assessing the economic efficiency of bioenergy technologies in climate mitigation and fossil fuel replacement in Austria using a techno-economic approach. Applied Energy. 2011;88(11):3665-84.

[14] Hwangbo S, Lee S, Yoo C. Optimal network design of hydrogen production by integrated utility and biogas supply networks. Applied Energy. 2017;208(Supplement C):195-209.

[15] United States Environmental Protection Agency. Sources of Greenhouse Gas Emissions. 2017.

[16] Makaruk A, Miltner M, Harasek M. Membrane biogas upgrading processes for the production of natural gas substitute. Separation and Purification Technology. 2010;74(1):83-92.

[17] Hagh BF. Optimization of autothermal reactor for maximum hydrogen production. International Journal of Hydrogen Energy. 2003;28(12):1369-77.

[18] de Souza TL, Rossi CdCRdS, Alonso CG, Guirardello R, Cabral VF, Fernandes-Machado NRC, et al. Thermodynamic analysis of autothermal reforming of methane via entropy maximization: Hydrogen production. International Journal of Hydrogen Energy. 2014;39(16):8257-70.

[19] Choudhary VR, Mondal KC. $\mathrm{CO}_{2}$ reforming of methane combined with steam reforming or partial oxidation of methane to syngas over $\mathrm{NdCoO}_{3}$ perovskite-type mixed metal-oxide catalyst. Applied Energy. 2006;83(9):1024-32.

[20] Jang W-J, Jeong D-W, Shim J-O, Kim H-M, Roh H-S, Son IH, et al. Combined steam and carbon dioxide reforming of methane and side reactions: Thermodynamic equilibrium analysis and experimental application. Applied Energy. 2016;173(Supplement C):80-91. 
[21] Singha RK, Shukla A, Yadav A, Adak S, Iqbal Z, Siddiqui N, et al. Energy efficient methane trireforming for synthesis gas production over highly coke resistant nanocrystalline $\mathrm{Ni}-\mathrm{ZrO}_{2}$ catalyst. Applied Energy. 2016;178(Supplement C):110-25.

[22] Vita A, Italiano C, Ashraf MA, Pino L, Specchia S. Syngas production by steam and oxy-steam reforming of biogas on monolith-supported $\mathrm{CeO}$-based catalysts. International Journal of Hydrogen Energy. 2018;43(26):11731-44.

[23] Sun D, Li X, Ji S, Cao L. Effect of $\mathrm{O} 2$ and $\mathrm{H} 2 \mathrm{O}$ on the tri-reforming of the simulated biogas to syngas over Ni-based SBA-15 catalysts. Journal of Natural Gas Chemistry. 2010;19(4):369-74.

[24] Winter S, Olsson H. Steam reforming solutions. 2007.

[25] Seo YS, Shirley A, Kolaczkowski ST. Evaluation of thermodynamically favourable operating conditions for production of hydrogen in three different reforming technologies. Journal of Power Sources. 2002;108(1-2):213-25.

[26] Ávila-Neto CN, Dantas SC, Silva FA, Franco TV, Romanielo LL, Hori CE, et al. Hydrogen production from methane reforming: Thermodynamic assessment and autothermal reactor design. Journal of Natural Gas Science and Engineering. 2009;1(6):205-15.

[27] Jarungthammachote S, Gratutito MKB. Thermochemical Study of Biogas Autothermal Reforming. Conference Thermochemical Study of Biogas Autothermal Reforming, Sofitel Centara Grand, Bangkok, Thailand.

[28] Vita A, Pino L, Cipitì F, Laganà $M$, Recupero V. Biogas as renewable raw material for syngas production by tri-reforming process over $\mathrm{NiCeO}_{2}$ catalysts: Optimal operative condition and effect of nickel content. Fuel Processing Technology. 2014;127:47-58.

[29] Effendi A, Hellgardt K, Zhang ZG, Yoshida T. Optimising $\mathrm{H}_{2}$ production from model biogas via combined steam reforming and CO shift reactions. Fuel. 2005;84(7-8):869-74.

[30] Larentis AL, de Resende NS, Salim VMM, Pinto JC. Modeling and optimization of the combined carbon dioxide reforming and partial oxidation of natural gas. Applied Catalysis A: General. 2001;215(1-2):211-24.

[31] Kiker GA, Bridges TS, Varghese A, Seager PT, Linkov I. Application of multicriteria decision analysis in environmental decision making. Integrated Environmental Assessment and Management. 2005;1(2):14.

[32] Loken E. Use of multicriteria decision analysis methods for energy planning problems. Renewable and Sustainable Energy Reviews. 2007;11(7):11.

[33] R. Lahdelma PS, J. Hokkanen. Using multicriteria methods in environmental planning and management. Environmental Management. 2000;26(6):11.

[34] Scott JA, Ho W, Dey PK. A review of multi-criteria decision-making methods for bioenergy systems. Energy. 2012;42(1):146-56.

[35] Jato-Espino D, Castillo-Lopez E, Rodriguez-Hernandez J, Canteras-Jordana JC. A review of application of multi-criteria decision making methods in construction. Automation in Construction. 2014;45:151-62.

[36] Li X, Wang K, Liu L, Xin J, Yang H, Gao C. Application of the Entropy Weight and TOPSIS Method in Safety Evaluation of Coal Mines. Procedia Engineering. 2011;26:2085-91.

[37] Jingwen H. Combining entropy weight and TOPSIS method for information system selection. Conference Combining entropy weight and TOPSIS method for information system selection. p. 12814.

[38] Sun L-y, Miao C-I, Yang L. Ecological-economic efficiency evaluation of green technology innovation in strategic emerging industries based on entropy weighted TOPSIS method. Ecological Indicators. 2017;73:554-8.

[39] Wang E, Alp N, Shi J, Wang C, Zhang X, Chen H. Multi-criteria building energy performance benchmarking through variable clustering based compromise TOPSIS with objective entropy weighting. Energy. 2017;125:197-210.

[40] Amiri MP. Project selection for oil-fields development by using the AHP and fuzzy TOPSIS methods. Expert Systems with Applications. 2010;37(9):6218-24. 
[41] Ma J, Fan Z-P, Huang L-H. A subjective and objective integrated approach to determine attribute weights. European Journal of Operational Research. 1999;112(2):397-404.

[42] Liu F, Zhao S, Weng M, Liu Y. Fire risk assessment for large-scale commercial buildings based on structure entropy weight method. Safety Science. 2017;94:26-40.

[43] Aunsup P, Patcharavorachot $Y$, Assabumrungrat S, Arpornwichanop A. Comparison of Different Hydrogen Production Processes from Biogas: Thermodynamic Analysis. Conference Comparison of Different Hydrogen Production Processes from Biogas: Thermodynamic Analysis, Hatyai, Songkhla, Thailand.

[44] Amin NAS, Yaw TC. Thermodynamic equilibrium analysis of combined carbon dioxide reforming with partial oxidation of methane to syngas. International Journal of Hydrogen Energy. 2007;32(12):1789-98.

[45] Li Y, Wang Y, Zhang X, Mi Z. Thermodynamic analysis of autothermal steam and $\mathrm{CO}_{2}$ reforming of methane. International Journal of Hydrogen Energy. 2008;33(10):2507-14.

[46] Gopaul SG, Dutta A. Dry reforming of multiple biogas types for syngas production simulated using Aspen Plus: The use of partial oxidation and hydrogen combustion to achieve thermo-neutrality. International Journal of Hydrogen Energy. 2015;40(19):6307-18.

[47] Corigliano O, Fragiacomo P. Technical analysis of hydrogen-rich stream generation through $\mathrm{CO}_{2}$ reforming of biogas by using numerical modeling. Fuel. 2015;158:538-48.

[48] AspenTech: Optimizing Process Manufacturing.

[49] Thomaser T. Analysis and optimization of an industrial scale pre-combustion $\mathrm{CO}_{2}$ capture unit of an IGCC power plant: Politecnico di Milano, 2013.

[50] Schefflan R. Teach Yourself the Basics of Aspen Plus. Wiley ed. Hoboken, New Jersey2011.

[51] Chein R-Y, Wang C-Y, Yu C-T. Parametric study on catalytic tri-reforming of methane for syngas production. Energy. 2017;118:1-17.

[52] Shannon CE. A Mathematical Theory of Communication. The Bell System Technical Journal. 1948;27:379-423.

[53] Hwang CL, Yoon K. Multiple Attribute Decision Making. New York: Springer, 1981.

[54] Wu J, Sun J, Liang L, Zha Y. Determination of weights for ultimate cross efficiency using Shannon entropy. Expert Systems with Applications. 2011;38(5):5162-5.

[55] Kumar R, Jagadish, Ray A. Selection of Material for Optimal Design Using Multi-criteria Decision Making. Procedia Materials Science. 2014;6:590-6.

[56] Wang Q, Wu C, Sun Y. Evaluating corporate social responsibility of airlines using entropy weight and grey relation analysis. Journal of Air Transport Management. 2015;42:55-62.

[57] Zou Z-h, Yun Y, Sun J-n. Entropy method for determination of weight of evaluating indicators in fuzzy synthetic evaluation for water quality assessment. Journal of Environmental Sciences. 2006;18(5):1020-3.

[58] Simpson AP, Lutz AE. Exergy analysis of hydrogen production via steam methane reforming. International Journal of Hydrogen Energy. 2007;32(18):4811-20.

[59] Hakawati R, Smyth BM, McCullough G, De Rosa F, Rooney D. What is the most energy efficient route for biogas utilization: Heat, electricity or transport? Applied Energy. 2017;206(Supplement C):1076-87.

[60] Strait M, Allum G, Gidwani N. Synthesis gas reformers.

[61] Udengaard NR. Hydrogen production by steam reforming of hydrocarbons. 2004.

[62] Rostrup-Nielsen JR, Rostrup-Nielsen T. Large-Scale Hydrogen Production. CATTECH. 2002;6(4):150-9.

[63] Yamazaki O, Tomishige K, Fujimoto K. Development of highly stable nickel catalyst for methanesteam reaction under low steam to carbon ratio. Applied Catalysis A: General. 1996;136(1):49-56.

[64] The Institute for Industrial Productivity. Lower Steam to Carbon Ratio on Reformer.

[65] Shiratori Y, Ijichi T, Oshima T, Sasaki K. Internal reforming SOFC running on biogas. International Journal of Hydrogen Energy. 2010;35(15):7905-12. 
[66] Starr K, Gabarrell X, Villalba G, Talens L, Lombardi L. Life cycle assessment of biogas upgrading technologies. Waste Management. 2012;32(5):991-9. 